\title{
Relations between China and Latin America: Inter-regionalism beyond the Triad
}

\author{
Bernadett Lehoczki \\ Institute of International Relations, Corvinus University Budapest \\ Email: bernadett.lehoczki@uni-corvinus.hu
}

Inter-regionalism refers to regular forms of cooperation between regions or actors from different regions and is a result of the parallel phenomena of globalization and regionalism. Inter-regional links are rapidly developing all around the world and form a new level of global governance. Though originally inter-regionalism typically connected the actors of the socalled Triad, today emerging economies and developing regions are more active and visible participants of inter-regional cooperation. The article examines the perspectives and limitations of inter-regional relations between China and Latin America as a new dimension of deepening Sino-Latin American relations.

Keywords: inter-regionalism, China, Latin-America

JEL-codes: F53, F55, O19

\section{Introduction}

Political and economic relations between China and Latin America go back centuries, but the end of the Cold War and of the bipolar international order brought new opportunities and a new chapter in Sino-Latin-American relations. After 2000 these opportunities widened further, therefore interaction between China and Latin American countries reached unprecedented dynamic and results.

Chinese foreign relations are determined by the motivation to strengthen foreign economic relations, therefore economic objectives are essential factors in Chinese foreign policy making. To maintain the pace of outstanding Chinese economic development, deepening economic and political relations are essential with foreign partners. Beijing has shown intense diplomatic activity in the past two decades, and as a result its cooperation has developed quickly with the 
Asian, African and Latin American region, but also with Europe and the United States (Ljunggren 2006). Since 2000 China has been much more active and has given a more constructive and less confrontational voice in foreign relations, especially compared to the Cold War period.

For Latin America, the end of the Cold War meant the victory of Western market democracy model, therefore Latin American countries continued the political and economic consolidation initiated in the 1980s, following the recipe of Washington and the international financial institutions. By 2000 most Latin American countries managed to build stable political and economic frameworks and institutions, but poverty, social inequality, social marginalisation remained widespread phenomena, while political parties lost credibility, widespread corruption and lack of political representation resulted in social dissatisfaction. As a consequence, a new generation of political leaders emerged, who declared the need to make Latin America a pole in itself in international relations and this led to the search for new partners and alternative development paths.

These factors contributed to the fact that by today China-Latin America relations are an essential axis in South-South cooperation with a promise of an exchange of experience and common development. Deepening and strengthening links between the actors led to different forms of regular, in certain cases institutional cooperation. This paper focuses on the various forms of interregional cooperation between China and Latin America developed since the 1990s, and attempts to analyse motivations, results and challenges in each case. Inter-regional relations beyond the Triad are a relatively new phenomena in world affairs, but examining such links between China and Latin America, describing their main features is important, because these forms of inter-regionalism could serve as models for other actors of non-Triadic interregionalism. Compared to other developing regions, Latin America has been active in building subregional groupings since the 1960s, and has also been part of the Pan-American cooperation framework since the nineteenth century, meanwhile China is expected to be a central actor in building inter-regional relations between developing regions.

\section{Inter-/trans-regionalism in a changing world order}

The phenomenon of inter-regionalism interpreted as third-generation regionalism can be linked to the 1990s when regional groupings started to look outward as global players and 
relations between regions became a new forum for international relations. The idea of multiregionalism anticipates a world order based on global regionalization where systematic relations emerge between regional organizations of the world, which can ultimately become a new level and efficient form of global governance (Van Langenhove - Costea - Gavin 2004). This future was forecast by Guy Verhofstadt in September 2001, when he said that the G8 should be replaced by a G8 having a more satisfactory regional representation where representatives of EU (European Union), AU (African Union), Mercosur (Common Market of the South), ASEAN (Association of Southeast Asian Nations) and NAFTA (North American Free Trade Agreement) would have an equal position for negotiation (Söderbaum - Van Langenhove 2005). For the time being regional groupings are not likely to take over the place of nation states, inter-regional frameworks, however, become increasingly important and diverse therefore their significance in the international system is expected to grow.

The phenomenon of inter-regionalism has some preliminaries, its roots dates back several decades. In the 1950-1960s the ground of the so called 'first wave of regionalism' was the European integration, but soon several developing nations tried to follow the example and established regional economic groups. According to structuralist theorists, this wave of regionalism was the vehicle to set free developing regions from the exploiting system of the center-periphery. These institutions (beyond the European integration), e.g. the Andean Group, the Central American Common Market (CACM), the Organisation of African Unity (OAU) or ASEAN were operated by states of similar development levels; they were inward looking and protectionist blocks and operated within the frameworks of the Cold War, so membership did not cross the East-West borderline.

From the eighties one of the most determining world economic phenomena was the 'second wave of regionalism' - strengthening and deepening in parallel with globalization. In this period several new regional groupings established, while some already existing blocks got new impetus. Consequently today there are few countries that are not member of any regional organization and several countries take part in more organisations simultaneously. The groupings of the nineties show many new features compared to the integration groupings after the Second World War, therefore this phenomena is called 'new regionalism'. ${ }^{1}$ It is also

\footnotetext{
1 These new regional groupings are more flexible, have looser institutional structures, and are the main 'supporters' of free trade against state intervention in the economy (Hänggi - Roloff - Rüland 2006). Their activity is more complex, and they have a wider range of objectives than their ancestors. This multidimensionality means the fading away of boundaries between political, economic, cultural etc. dimensions.
} 
called 'open regionalism' referring to the extroverted attitude of these integrations - in contrast with the often protectionist practice of the first generation -, as now integration into the global economy was a central objective. Another novelty was that developed and developing countries could get into one block (e.g. NAFTA), and also the institutional structure of these regional groupings was less sophisticated compared to that of the first generation, however, these organizations have typically multiple objectives. Beyond economic integration, participants embarked on political, defence and cultural cooperation. At the same time there is no clear borderline between the two waves of regionalism, but due to the consequences of accelerating globalization, remission of the Cold War and new phenomena of the world economy, the existing regional structures responded similarly and the new blocks were established in the context of these new circumstances.

The main innovation of inter-regionalism was that while the first two generations of regionalism emphasized the strengthening of the regions themselves, third generation integration includes relations outside regions and harmonization with other regions. In this wave of regionalism the regions are 'looking outward' and initiating agreements on various topics with other regions. In the beginning the European Union was the 'leader' of this phenomenon but today integration blocks in other continents (inter alia ASEAN and Mercosur) are increasingly active in approaching other regions (Van Langenhove - Costea 2005).

Inter-regional relations are the logical and chronological consequence of regional integration. It is about how the institutions of new, open regionalism build relations with each other. So at this wave of regionalism geographical proximity loses its importance. The main reason for the institutionalization of interregional relations is that there is some kind of systematization of the more and more complex and interdependent world and this is a way in which regions are wishing to compensate the alliances of other regions (Hänggi 2000).

In the beginning the European integration's so called group to group concept formed the basis of thinking. In the 1990 s the third generation of regionalism basically meant the relation system of the so called members of the Triad. The basic of the Triad concept was formed by the trilateral relations between the USA, the European Communities and Japan - the three powers of the capitalist world economy - during the Cold War period. In the meantime this 
concept has changed referring to the relation system of three regions (North America, Western Europe and East Asia). In the last decades of the twentieth century the members of the Triad accounted for three quarters of global trade, $90 \%$ of foreign direct investment (FDI) and also $85 \%$ of the world's GNP (Hänggi 2000). Initiative like the APEC (Asia-Pacific Economic Cooperation), established in 1989, the New Transatlantic Agenda of 1995 between the USA and the European Union, the Transatlantic Economic Partnership of 1998 and finally the Asia-Europe Meeting (ASEM) between Western Europe and Asia launched in 1996 meant the basic frameworks for inter-regionalism. These inter-regional groupings linked the members of the Triad, boosting their position in global economic processes.

After the turn of the Millennium, however, regional groupings of the developing world also began to participate in building global inter-regionalism. One of the major reasons for this is the increasing fragmentation of the developing world both in terms of political influence and economic performance. The dynamic economic growth of the so-called emerging powers seem to pose a real challenge to the global order dominated by Triad members, in that they appear as new centres of power, even building their own regional groups to support themselves. The strengthening position of emerging powers is a prime factor concerning the uniform opinion of the international literature relating to the twenty-first century world order moving towards multipolarity. While in the 1990s the issue of unipolar/multipolar world order was in the centre of debates, today the latter scenarios seems relevant and the debate revolves rather about where poles and the centre of these poles will be. Not surprisingly, emerging powers and members of the developing world are more and more active in building interregional relations, as on the one hand this is a prerequisite for strengthening their positions and on the other hand it enables them to participate in global governance more powerfully than ever before, and for developing countries in can be useful for the purpose of avoiding marginalization. In the 1990s the European Union - continuing its policy of the previous years - strengthened its relations with Africa, Asia and Latin America, but now we can see that the emerging powers of these continents will be active initiators especially when building relations outside the Triad. Based on the above, inter-regional relations can (also) be categorized as follows: inter-regional relations inside the Triad; between a triadic member and a different region of the world; and between non-triadic members. The last type of relations is still in its infancy, it is more like first attempts or getting to know each other rather than building institutionalized relations. For this reason the theories describing inter-triadic relations cannot really be applied to these relations, studying them, however, is relevant 
because they are expected to strengthen and inter-regional cooperation will have typical traits the same way as integrational groupings of other regions have their own specific traits in comparison with the European Union.

The three waves of regionalism are summed up in Table 1.

Table 1. Three Waves of regionalism

\begin{tabular}{|c|c|c|c|c|}
\hline & When & Features & Actors & Examples \\
\hline Old regionalism & $1950 \mathrm{~s}-1970 \mathrm{~s}$ & $\begin{array}{l}\text { inward looking } \\
\text { policies } \\
\text { protectionism, deep } \\
\text { institutions }\end{array}$ & $\begin{array}{l}\text { States with } \\
\text { similar economic } \\
\text { and political } \\
\text { background }\end{array}$ & $\begin{array}{l}\text { EEC, Andean Group, } \\
\text { NATO, ASEAN, } \\
\text { CoE }\end{array}$ \\
\hline $\begin{array}{l}\text { New/open } \\
\text { regionalism }\end{array}$ & 1980s- & $\begin{array}{l}\text { extroverted policies } \\
\text { with the aim of } \\
\text { integration into the } \\
\text { world economy } \\
\text { free trade, minimal } \\
\text { state intervention } \\
\text { loose institutions } \\
\text { multiple objectives }\end{array}$ & $\begin{array}{l}\text { States with } \\
\text { geographical } \\
\text { proximity }\end{array}$ & $\begin{array}{l}\text { EU, } \quad \text { Mercosur, } \\
\text { NAFTA, OSCE, AU }\end{array}$ \\
\hline Inter-regionalism & 1990s- & $\begin{array}{l}\text { looking outward } \\
\text { strengthening } \\
\text { cooperation with } \\
\text { other regions } \\
\text { multiple objectives } \\
\text { geographical } \\
\text { proximity loses its } \\
\text { importance }\end{array}$ & $\begin{array}{l}\text { States, regions, } \\
\text { subregions, } \\
\text { regional } \\
\text { organisations }\end{array}$ & $\begin{array}{lr}\text { APEC, } & \text { ASEM, } \\
\text { FEALAC, } & \text { EU- } \\
\text { Mercosur, } & \text { China- } \\
\text { CELAC } & \end{array}$ \\
\hline
\end{tabular}

Source: author

Hänggi's often referred categorization distinguishes three groups of inter-regional relations (Hänggi 2000):

A) Relations between regional groupings. These can be considered the prototype of interregional arrangements, a relationship that is closely linked to 'old regionalism'. Examples are the EU-Mercosur, EU-Andean Community, EU-Rio Group, ASEANMercosur, ASEAN-Rio Group, and CER (Closer Economic Relations, a free trade agreement between Australia and New Zealand)-Mercosur relations.

B) Biregional and transregional relations. These are a rather recent phenomenon in international relations. Membership in these rather heterogeneous arrangements is more diffuse than in traditional group-to-group dialogues; it does not necessarily 
coincide with regional groupings and may include member states from more than two regions. Examples are APEC, Europe-Latin America Forum, Forum for East AsiaLatin America Cooperation (FEALAC) and the Free Trade Area of the Americas (FTAA).

C) Hybrid systems. These are relations between regional groupings and single powers in other world regions. Relations between China and Latin America mostly give this form of interregional cooperation, like China-Mercosur, China-Community of Latin American Countries (CELAC) and China-Pacific Alliance (PA) cooperation.

Actors of inter-regionalism seem difficult to define and grasp; they can be states, regional organizations/groups and regions. The term 'region' requires a flexible interpretation relating to a continent, geographical area or areas difficult to define such as Latin America. In the case of interstate relations, actors form their opinions and take part in negotiations through established mechanisms. As to inter-regional relations, the internal structure of actors is mostly under development and change, so most of the time common actions are difficult to take and require preliminary internal negotiations. Another important feature is that interregional relations are often asymmetric because mostly regions with different levels of development are connected. The fundamental question influencing the future impacts of interregionalism is how much the initiator emerging powers will follow the traditional centreperiphery relation between developed-developing countries in their inter-regional relations and how much they will be able to move beyond that.

The difference between inter-regionalism and inter-regional cooperation depends on the existence or lack of institutions. Although the two phenomena are difficult to separate and in my opinion it is not even worth it because of the diversity of actors on the one hand and the fact that inter-regional relations are looser and often ad hoc without institutions, on the other (e.g. BRICS - Brazil, Russia, India, China and South Africa, IBSA - India, Brazil, South Africa forums). We should not exclude these formations from the study of inter-regionalism since considering global economic trends, emerging powers are expected to become ever more active builders of inter-regional relations. Moreover the so called hybrid forms begin to take over the European practice following the group to group concept: for example the annual EU-Brazil and EU-China Summit. A general feature is that inter-regional relations today - as yet - miss actual institutional frameworks; instead there are regular ministerial meetings i.e. forums which systematize the relations of each region/regional groupings. We can see that an 
important feature of inter-regionalism is the diversity of actors and the diversity of cooperation forms.

The literature on this phenomenon ${ }^{2}$ has only reached the surface of the process, since the contours are misty, and it is by far not a linear, even process. Some authors state that interregionalism is one of the most focused and regulated forms of globalization (Hettne 2004), which can be an important handhold and framework in today's world order/disorder. Researchers agree that inter-regionalism is a long term, uncertain, but irreversible process. The end product could be multiregionalism that would mean a new, regionalized form of multilateral world order in which inter-regional relations dominate. Today agreements among regions are voluntary and cooperative, but in the future these could become institutionalized, which would affect the structure of the world order (Hettne 2005).

The future direction and frameworks of inter-regionalism will highly depend on how much the triadic members will be interested in building inter-regional relations, how much they will promote the strengthening of inter-regional frameworks. The geopolitical and geoeconomic position of regions outside the Triad will fundamentally be defined by how successful their inter-regional relations with each triadic member and with each other will be. The significance of inter-regionalism beyond the Triad lies in that it can open a new chapter in South-South cooperation, if cooperation between these regions receives a systematic structure supported by active participation of emerging powers, which can help disadvantaged countries catch up (or at least hang on, provided that they are part of the system). It may also extend economic opportunities and the political influence of these regions.

\section{Relations between China and Latin America}

\subsection{A Historical background}

The system of relations between Latin America and China is not a new phenomenon, their trade relations date back as early as the nineteenth century, following the independence wars in Latin America (1810-1824). However, Sino-Latin American relations virtually ceased later on as the new Latin American republics increasingly focused their attention on meeting the

\footnotetext{
${ }^{2}$ Researchers studying inter-regionalism are mainly representatives of new regionalism's research, e. g. Hänggi, Hettne or Söderbaum. This is because of the relatively short time period between the second and third wave and the fact that many features of inter-regionalism are logical consequences of the characteristics of new regionalism.
} 
increasing European demand. Latin American countries - following the United States established diplomatic relations with China in the 1970s, and when the People's Republic of China (PRC) took its seat in the UN Security Council, the world organization opened as a new forum for the Sino-Latin American cooperation. During that decade the People's Republic of China supported several UN proposals especially important for Latin America (Panama's demand for the sovereignty over the canal, the New International Economic Order, and Latin American Nuclear Weapons Free Zone). As of the 1960s, the first Latin American integration groupings emerged (Latin American Free Trade Association (LAFTA), Andean Group, CACM, CARICOM (Caribbean Community)) with the purpose to support the competitiveness of the region on global markets, but fitting in the first wave of regionalism these were basically inward looking and not seeking foreign relations. During the Cold War years China stayed away from regional groupings, making it unable to start inter-regional cooperation.

The Chinese economic reform process starting in 1978 had a positive impact on possible interactions between China and Latin America, and in the 1990s the end of the Cold War posed similar challenges to China and Latin America such as poverty, social inequality, fear of marginalization, which helped improve inter-regional relations. In 1990 a political dialogue commenced between China and the Rio Group, in 1994 China became the first Asian observer in the Latin American Integration Association. In 1997 China joined the Caribbean Investment Bank (Shixue 2001). APEC, established in 1989, was the first - according to the categorization above - transregional community where besides China (in 1991), Latin American countries (Mexico 1993, Chile 1994, Peru 1998) could also become full members with Columbia, Panama and Ecuador aspirant members. Although the launch of APEC affected Sino-Latin American relations indirectly as the first regular, institutionalised regional forum where China and Latin American countries are represented, the literature sees APEC rather as an element of an inter-regional system within the Triad linking North America and East Asia.

\subsection{Current political and economic relations}

The 2000s were an important milestone in the relation between China and Latin America as the sporadic relations of the past became an increasingly conscious strategy building on both (but mainly Chinese) sides, the basis of which is provided by the increasingly active trade 
relations with China's demand for raw materials in the background. The World Trade Organisation (WTO) membership of the PRC vastly promoted the growth of trade between the parties by fostering bilateral negotiations on free trade. This process was complemented by the so called left turn in the Latin American region, after the problematic results of the Washington Consensus interpreted as a Western recipe for development. Newly elected leftwing presidents seemed open to alternative directions of economic development and the diversification of foreign trade relations was set as a fundamental objective. Similarly, China, under the flag of 'peaceful rise' has become more devoted to strengthening its economic and political presence inside the developing world. After 2000 the 'institutionalization' of Chinese relations got new impetus in Latin America: the Asian country became an observer in Parlatino in 2004 and also in the Organization of American States (OAS) (Lei 2006). In 2009 the PRC joined the Inter-American Development Bank (IADB) as the third Asian country after Japan and South Korea, which suggests long-term Chinese objectives in the region (IADB 2009).

In November 2008 the Chinese Ministry of Foreign Affairs issued a so called White Book on its Latin American objectives. This was the first official document on Beijing's Latin American relations. ${ }^{3}$ Chapter 5 of this document elaborates on the relations between Beijing and the Latin American integration organizations, which indicates that besides bilateral relations, the Chinese government regards Latin American regional groupings as partners too. $^{4}$

As mentioned above, trade relations between China and Latin America received an impetus around the turn of the Millennium. The world economic crisis of 2008-2009 offered further opportunities for the Sino-Latin American relations due to the decreasing demand for Latin American products in the US and Europe. Between 2000 and 2014 trade between China and Latin America increased twenty-fold from USD 12.6 billion to USD 261.6 billion (Yang 2015). By way of comparison, Latin America's trade with the world grew just three-fold over the same period. The region's exports to China have been especially robust, increasing $27-$ fold between 2000 and 2013 while imports rose 20-fold in the same period. However, most Latin American countries show a persistent and growing trade deficit with China. Brazil, Chile and the Bolivarian Republic of Venezuela are the only exceptions to this trend (CEPAL

\footnotetext{
${ }^{3}$ Similar White Books were issued by China on the EU in 2003 and on Africa in 2006.

${ }^{4}$ Full text of the White Book can be accessed here: http://www.gov.cn/english/official/2008-

11/05/content_1140347.htm
} 
2015a). By today, China's share of Latin America's exports is over 10\%, while its share of imports has reached 16\%. The United States is still Latin America's number one trading partner, but the US share in Latin American exports has shown steady decline since 2000 (from $58 \%$ to $40 \%$ ), and a similar tendency is seen in imports, the share of the US declined from 49\% to 31\% in Latin American imports (CEPAL 2015a). By 2010 China had already taken the European Union's place as the second largest source of imports to Latin America and it is on the way to become the second largest market for Latin American and Caribbean exports, replacing the EU on this position. In 2013 China 'was the single largest destination of exports from Brazil, Chile and Cuba, the second largest for Argentina, Colombia, Peru and the Bolivarian Republic of Venezuela, the third largest for Panama and Uruguay and the fourth largest for Mexico and the Dominican Republic. As a source of imports China's rise is even more marked; in 2013 it ranked as one of the four main suppliers for virtually every country of the region' (CEPAL 2015a). On the other hand, it has to be mentioned that the slower growth of China since 2012 has resulted in reduced demand for raw materials and 2014 was the first year when Latin American exports to China decreased in this century (CEPAL 2015b). This means that the extremely rapid trade growth of the 2000s might slow in the coming years.

It is important to emphasize the high concentration of export products targeting the Chinese market from Latin American countries. In most Latin American countries the highest number of products is exported to regional markets, the US and the EU are in an intermediate position in this sense, while the smallest number of products heads for China and Japan. About Latin American exports to China we find that '[...] commodity exports make up the largest share by far. Among them are oil, iron ore, copper in different forms, soybeans, scrap metals, fishmeal, wood and sugar. Except for products in the soybean chain, agricultural and agroindustrial products still make up a very small share of the region's basket of exports to China.' (CEPAL 2015a). As Latin American manufactured goods are not competitive in the Chinese (nor in the Asian) market, the basis of biregional trade is given by the huge Chinese demand for raw materials. As a consequence, the Chinese market is an opportunity for large raw material exporters in Latin America, especially in South America.

While trade relations between China and Latin America have increased significantly since 2000, bilateral FDI flows have only risen sharply since 2010 - so a decade-long delay can be detected between the two. According to ECLAC estimations in the two decades prior to 2010, the region's inward FDI from China totalled some USD 7 billion, but in 2010 the inflow of FDI from China approached an estimated USD 14 billion - equivalent to $11 \%$ of the region's 
total inward FDI (CEPAL 2015a). It was also in 2010 that Chinese investments came to the attention of governments, companies and civil society in Latin America, and 'although the reception was largely positive, regulations were tightened in some specific sectors' (CEPAL 2013).

As it is seen from the analysis of trade relations, Latin American exports targeting Chinese market are mostly raw materials and Chinese FDI in the region mirrors this tendency. "Almost 90\% of estimated Chinese investments between 2010 and 2013 went to natural resources; only $25 \%$ of the region's total inward FDI during the same period went to that sector' (CEPAL 2015a). Oil and gas extraction is an important focus of Chinese FDI in Latin America - with the involvement of Venezuela, Colombia, Ecuador, Peru, Brazil and Argentina. Another important sector targeted by Chinese FDI is infrastructure, with more or less the same host countries. Brazil is the only Latin American country receiving significant Chinese investments in the manufacturing sector with the aim to serve the local market. 'Chinese companies tend open a production plant after years of importing products from China; they do so either to gain proximity to and knowledge of the local market or to circumvent import restrictions' (CEPAL 2015a). Mexico is another Latin American economy where Chinese FDI arrives in the manufacturing sector, but here the objective is to export end-products to other markets, especially the United States. Compared to other regions we find that the 'US (25\% of the total) and the EU (40\%) continue to be the largest sources of FDI for Latin America, and the share of China and other Asian economies remains modest (7\%)' (CEPAL 2013). This means that unlike trade relations, investments flow between China and Latin America does not seem to change significantly the patterns of past decades, in this case a much slower change is expected.

Latin American investments to China are limited in volume and scope, but show an increasing tendency. Brazil and Chile are the main actors, for example Brazilian manufacturing firms Marco Polo and Embraer, and Chile's Molymet (molybdenum processing) are present in the Chinese market (CEPAL 2015a).

\subsection{Motivations}

To understand the nature, opportunities and limits of Chinese-Latin American inter-regional relations it is important to define what interests and motivations drive parties to build relations of this kind. 
Political leaders of the Latin-American region realized that China plays an increasingly crucial role in the world economy; it has become an indispensable actor. The relationship with China is important for countries in the Latin American region, being another connecting point to world economy; it can help the region's integration into the world economy and its headway in world trade.

The Asian country may play an important role in the diversification of Latin-American export and in decreasing the dependency from the United States and Europe. The Chinese expansion in the world economy and the more and more dynamic trade with certain countries in the region create an opportunity for Latin America to strengthen multipolarity in its international trade relations. For this purpose building inter-regional institutions seems an adequate instrument, as it contributes to regular contacts between parties. After World War Two Latin American foreign affair and foreign trade relations were clearly limited to the United States, during the decades of the Cold War the Colossus of the North was the most important partner for the countries of the region, except for Cuba and also Chile had some alternative routes, where as early as during the Pinochet regime foreign trade policy was driven by diversification. In the 1980s Japan and the European integration emerged as new, potential partners for Latin America, which alleviated dependency from the USA, but the depressing dominance in the foreign relations with the United States remained, especially in Mexico, the Central American countries and the Andean region. The rise of China (and India) in the world economy, their rapid economic growth, increasing demand and ability as well as willingness to invest are certainly a diversification potential for Latin America.

For Latin America the Chinese market of 1.3 billion people, its ever increasing demand for raw material and food are a serious potential. Chinese demand is a reliable and steady source of income for those Latin American countries which have the abundant raw materials necessary for China.

Since the turn of the Millennium China has become an increasingly important FDI source in the world. This can positively affect the Latin American region if the volume of Chinese investments can be further increased. It needs to be emphasized that a significant part of Chinese investments is directed at the improvement of infrastructure in Latin America, which can contribute to a deeper integration of Latin America into the world economy and developing trade with different regions and also further diversification (Lehoczki 2009). 
Since the end of the Cold War, an important objective of Latin America, especially South America, is to have its voice heard on international forums as an independent actor, build autonomous foreign policy with other countries as well as subregions and also with the region as a whole. China could be a potential partner by extending interregional cooperation, with the help of institutions Latin America can improve its international prestige, acknowledgement and last but not least its bargaining power with the United States. For Latin American countries China represents the possibility of building mutually beneficial horizontal co-operation looking for mutual development (Armony - Strauss 2012), which brings the promise that after centuries of asymmetrical, hierarchical relations with foreign partners (the United States and European countries), a new type of extra-hemispherical actor appears in Latin America's foreign relations.

As for China, similar interests and motivations are outlined. Building relations with peaceful, politically stable governments in Latin America fits perfectly with the Chinese rhetoric of 'peaceful rise' and 'mutual benefit'. For the dynamically improving Chinese economy, Latin America is a reliable source of raw material and food. To maintain the incredible growth and modernization of the Chinese economy, the continuous supply of raw material is indispensable. Since 1999 the growth rate of Chinese heavy industry has surpassed that of light industry. The maintenance of heavy industry is fundamental to keeping economic growth at the same level. Similarly, the continuous import of raw materials is indispensable to maintain production, as well as the stabilization of supply. Food takes a leading role in China's imports from Latin America, which is due to the fact that China is unable to solve the population's food supply alone.

Latin American markets are reliable importers of China's cheap finished product. Due to the debt crisis which swept over the region in the 1980s, the middle class in Latin America melted down, however they are expected to recover in the coming decades to become the basis of an increasingly significant market. Beijing believes that Latin America will steadily import a wide range of Chinese products.

After the Cold War, Chinese foreign policy became a crucial priority for the international order in order to prevent the consolidation of a unipolar world order driven by the United States. Strengthening multipolarity and multilateralism in international relations has become a strategic cornerstone of Chinese foreign policy, an important instrument of which is joining the developing world, its joint representation on international forums and improving its position of 
negotiation. To reach this goal, Latin American countries can be important partners for China because their international prestige exceeds that of Africa, and unlike in Asia, their relation to China are not spoiled by regional competitions. Also, it is important to emphasize that the Chinese presence in Latin America is an integral part of a more general policy of 'going out' and needs to be interpreted in this wider context. China's involvement is the most intensive in South-East Asia, it shows a high profile involvement with Africa and a relatively minimal presence in the Middle East. In this perspective, Latin America's position is somewhere between Africa and the Middle East in China's foreign relations (Armony - Strauss 2012).

Since the founding of the PRC in 1949, the Taiwan issue and the related One-China principle has always been a basic foreign affairs priority. A fundamental objective for Beijing is that among countries currently recognizing the Republic of China, more and more should recognize the PRC. In Latin America there are 12 countries, especially in Central America and the Caribbean, recognizing Taiwan, therefore the region is an important bastion for the Republic of China (ROC). Building inter-regional relations, especially the China-CELAC forum (see below) can be a proper instrument for Beijing to convince Latin American countries recognizing Taiwan to establish diplomatic relations with the PRC (a prerequisite of which is to stop recognising Taiwan, obviously) (Lehoczki 2009).

\subsection{Forms of cooperation}

Institutionalized relations between Asia and Latin America are relatively new; traditionally, Latin America was building similar relations with the United States and Europe. During the process of Asian regionalism, China remained an isolated actor until the end of the 1990s. Besides, the so-called transpacific relations were originally tied between North America and East Asia as two members of the Triad. In this system, Latin American countries as well as China are new players. Within the system of inter-regional relations the institutionalized frameworks between Asia and Latin America can be translated into peripheral interregionalism. Relations of this type mostly follow the logic of diversification which helps the peripheral states alleviate dependency and their relations to the centre (Dosch 2005). As discussed above under motivations, the appearance of China (and Asia) in foreign relation creates a new perspective for the Latin American countries. 
Since the beginning of the 2000s China's share in foreign trade has increased in almost every Latin American country at the expense of the United States and Europe. In terms of interregional relations between Latin America and China, Brazil plays a central role in this system because as an emerging power it is an active participant in several transregional communities, being a main promoter of multilateral frameworks in the past two decades, as well as an innovator (founder of IBSA and initiator of South America-Africa, South America-Arab world cooperation frameworks) and also eminent actor of MERCOSUR and South American integration. The PRC tops the list of Brazil's foreign trade partners. Argentina, as an emerging country and member of Mercosur, is a significant actor, while Chile, Mexico and Peru are traditionally outward looking countries seeking free trade agreements throughout the world. Cuba and Venezuela also have active China policies, with the PRC becoming a significant trading partner in past decades, however their cooperation can rather be described as bilateral, therefore we are not touching upon this.

Interregional relations between China and Latin America are truly versatile and can be categorized as follows:

A) global frameworks and loose groupings of emerging/developing countries which's members include China and some Latin American country/countries such as G20, G21 and BRICS;

B) transregional groups which's members include China and some Latin American country/countries such as APEC and FEALAC;

C) institutionalized relations between China and a Latin American integration block such as Mercosur-China, Andean Community-China and CELAC-China cooperation.

The three types of cooperation work in parallel complementing each other, which reflects the connecting points of the two regions. The category of emerging countries links China with Brazil, Argentina and Mexico, the increasingly wider Asian-Latin American interregional framework provides regular a forum indirectly supporting Sino-Latin American relations, while China's intended strategy is cooperation with each region on forums where besides Africa and the Arab region Latin America is also affected. Groupings of emerging countries will not be discussed further as they are not closely related to the development of Sino-Latin American inter-regionalism, they work parallel with it. Their significance lies in that for the 
participating Latin American countries and China, these are important forums to articulate their interests, stand up for objectives by supporting each other, such as stabilizing the multipolar world order and South-South cooperation. In 2014 the BRIC meeting took place in Brazil, and the Chinese president also went on a tour of Latin America visiting Argentina, Venezuela, and Cuba. As a result more than 150 contracts and framework agreements were signed and also a grand plan was set up by China, Peru and Brazil to build a railway connecting the Pacific and the Atlantic Oceans (Swaine 2014).

As mentioned above, APEC was the first transregional organization which besides China also had Latin American members. The aim of the organization established in 1989 was to strengthen transpacific relations, however basically it still promotes the approach of the USAEast Asia axis. The limited participation of Latin American countries prevents the organizations from becoming an important forum of Asian-Latin American or Sino-Latin American relations. Out of the 21 member states of APEC only 3 are Latin American countries (Mexico, Chile, Peru), whose inclusion can mainly be explained by their geographical location. Within APEC, Latin American countries do not have the power to shape opinions, there have been no actual results to promote Asian-Latin American relations apart from annual meetings of Asian and Latin American members within the frameworks of the forums. However APEC indirectly still contributed to the strengthening of inter-regional relations. In the past decade several Asian leaders went on tours of Latin America within the framework of APEC summit meeting. For example former Chinese president $\mathrm{Hu}$ Jintao went on a Latin American tour in $2004(\operatorname{Kim} 2003)$.

Besides current Latin American member states, Columbia and Ecuador expressed their desire to join APEC (as early as the 1990s), however, it is uncertain when they can actually do so. Questions can be raised as to where the limits of Latin American APEC membership are and how the extensions of the Asian-Pacific region are interpreted in geographical and economic terms because without the membership of Brazil and Argentina the Latin American participation is likely to remain inefficient.

A break-out from these transpacific frameworks and the beginning of the establishment of more direct Asian-Latin American relations were marked by the idea of Goh Chok Tong (then prime minister of Singapore) during his visit in Chile in 1998 to found an institution which would include East Asian and Latin American members (Dosch 2005). The chief motivating forces and anticipated functions of this initiation were as follows: due to the 1997-1998 Asian 
crisis the exchange of experience concerning the effects of neoliberal economic policy gained priority; the desire of ASEAN and other formations to represent their interests more effectively on international forums; Asian countries' fear of the effects of the FTAA (loss of market); complemented with ASEM, the forum can help counterweight the influence of the USA in East Asia; the same holds true for Latin America along with the EU-Latin America institution system (Low 2006).

In the beginning the working name of the idea was East Asia-Latin America Forum (EALAF), at the Inaugural Meeting of 199921 East Asian and Latin American countries were represented (Low 2006). In March 2001 the first meeting at foreign ministerial level was held where future cooperation was divided into three working groups: I. Politics, Culture and Education; II. Economy and Society; III. Science and Technology, which proves that members did their best to exceed the strengthening of trade and investment relations. The following year the name of the grouping was changed to FEALAC (Forum for East Asia - Latin America Cooperation), ${ }^{5}$ which replaced a missing link - institutional relations between Latin America and East Asia in the global interregional relation system. For Latin America the significance of this institution lies in its transregionality, as a result of which the states at the coast of the Atlantic (Argentina, Brazil, Uruguay), the countries without coastlines (Bolivia, Paraguay) and countries around the Caribbean Sea (Venezuela, Cuba) - contrary to APEC - can also be members. The first ministerial meeting took place in Santiago in 2001, where a professor from Singapore gave utterance to the demand for opening new dimensions for relations saying that the main obstacle to building Asian-Latin American relations was not the distance but the fact that the United States and European colonists defined relations between the two regions (Rouxel 2001).

The model for FEALAC was ASEM, institutionalizing relations between Asia and Europe, but its operation seems to have had slower dynamism so far. Firstly, this is due to the lack of an entity corresponding to the Asia-Europe Foundation (ASEF), secondly, a lack of political willingness to give dynamism to inter-regional relations and thirdly, mostly in relation with the above, the lack of coordination. No priorities were laid down, the scope and the agenda for ministerial meetings were too broad, and projects were run on a voluntary basis in a

\footnotetext{
${ }^{5}$ FEALAC is an association of 33 East Asian and Latin American countries, a new tool of dialogue and cooperation. The member states are Australia, Brunei, Cambodia, China, Indonesia, Japan, South Korea, Laos, Malaysia, Myanmar, the Philippines, Singapore, Thailand, New-Zealand, Vietnam; Argentina, Bolivia, Brazil, Chile, Columbia, Costa Rica, Cuba, Dominican Republic, Ecuador, El Salvador, Guatemala, Mexico, Nicaragua, Panama, Paraguay, Peru, Uruguay and Venezuela.
} 
decentralized manner. The future of the forum depends on how successful the deepening of institutions, the elaboration of specific programs at multilateral level and the breaking of cultural space between the parties will be (Wilhelmy - Mann 2005). At the same time the major result of FELAC is its existence and the broadening scope of the forum is just as reassuring, which indicates that East Asian and Latin American countries believe that the time has come to institutionalize their relations and also see a need to discuss an increasing number of in a wider circle, as well as exchange experience more frequently. However, among transregional agreements, FEALAC has limited political and economic significance, which can be explained by the fact that relations with the developed world have still priority for Asian and Latin American parties alike (Altemani de Oliveira 2010).

Relations between some Latin American integration groupings and China are said to be part of the so called hybrid type of institutionalized relations between Latin America and Asia. Among the integration groupings in the Latin American region, Mercosur pursues the most active foreign policy. Relations with the EU date back to the 1990s but after the turn of the Millennium (not least due to the Brazilian and Argentinean presidents Lula da Silva and Néstor Kirchner) Mercosur became clearly open towards regions of the developing world: in 2004 a detailed trade agreement with India and the South African Customs Union (SACU), and in May 2005 an economic cooperation agreement with the Gulf Cooperation Council (GCC) were concluded. In January 2004 Mercosur and India signed a preferential trade agreement in New Delhi (CEPAL 2005), the first step for a future free trade zone. In 1997 China initiated the launch of the China-Mercosur Dialogue Forum, followed by several meetings without any significant result though (Steinberg 2008). Among the members of the Common Market of the South, Brazil, Argentina and Venezuela have substantial trade relations with China. Brazilian and Argentinean industrial products, however, are vulnerable in the competition with Asia. In 2004, and again in 2012, the PRC brought up the establishment of a China-Mercosur free trade zone, however for Argentina and Brazil cheap Chinese finished products would create competition in the Mercosur markets for their own finished products, thus challenging the industrial situation in Brazil and Argentina. For Uruguay and Paraguay, Chinese import could be beneficial, but the Mercosur system offers a reliable market for their products. Nevertheless, in South America Mercosur member Paraguay is the only state maintaining diplomatic relations with Taiwan. Mercosur-China relations will improve in terms of each member's growing trade with China, and also because the strengthening of relations with China is a 
recurring topic at Mercosur meetings, but no advancements are expected at the level of institutions.

Relations between the Andean Community and China saw significant improvement in the 2000s with the parties signing the agreement establishing political consultation and cooperation mechanism in 2000, which was launched in 2002. China-Andean Community Consultation was launched in 2004 and in 2005 the major areas of cooperation were defined. In January 2005 the Chinese vice president met with the foreign ministers of the member states of the Andean Community during his Latin American visit to agree on strengthening future relations in general (People's Daily 2005). For the past decade, however, interregional relations seem to have stagnated, which is not least due to the internal challenges of the Andean Community. Among the members of the Andean Community, Peru's trade with China is the most significant; the two states concluded a free trade agreement in 2009 (Forbes 2009).

The establishment of the Pacific Alliance (PA) in 2012 including Mexico, Peru, Chile and Columbia might put the Andean Community-China relations in the background. Beyond the cooperation of member states, the grouping's objective is to build closer relations with the Asian-Pacific region. Founding states hope to be more successful in Chinese markets by supporting each other and reach stronger bargaining power towards China through common actions as opposed to doing it one by one (Ramírez 2013).

Besides Peru, Chile and China also signed a free trade agreement in 2005. Panama and Costa Rica are currently observing members in the PA, but they are expected to be granted full membership in the near future. Among the observing members of the grouping, there are several Asian countries including China. A crucial objective of the PA is to bridge the Latin American and Asian-Pacific regions and an important feature is that compared to other Latin American economic groupings it is an open and outward looking block. The motivation of members is basically economic: they aim to establish trade relations with Asian-Pacific countries including China and also increase the investments of China in member states.

States in the Caribbean and relations of CARICOM with China should also be noted here. China's trade with the region keeps growing, with Jamaica, Trinidad and Tobago, as well as the Bahamas being the most important partners. Beyond the improvement of trade relations, the Caribbean region has also political significance for China, since most of the countries recognizing Taiwan are located here. As a result, although China is a member of the Caribbean Development Bank and since 2005 the China-Caribbean Economic and Trade 
Cooperation Forum has had regular sessions, a serious obstacle to building inter-regional relations is that CARICOM members do not have a uniform opinion concerning the PRCTaiwan issue, so they are not able to formulate a coherent China policy, therefore the main forum of Sino-Caribbean cooperation is a set of bilateral relations. Similarly, in the relation system of Central America and China, a crucial obstacle to inter-regional relations is that except for Costa Rica each state maintains diplomatic relations with Taiwan. Moreover, trade relations are hindered by China being a competitor with Central American economies especially in US markets (Erikson 2009), therefore closer inter-regional cooperation has low probability.

One of the latest regional groupings in the Latin American region is the Community of Latin American and Caribbean States (CELAC), established in 2011, which's members include all sovereign states in the American continent except the United States and Canada. CELAC is an important actor of the so called post-hegemon regionalism referring to Latin American attempts to form regional groupings that go beyond US-led patterns of economic integration and involve 'new social fields as education, health, employment, energy, infrastructure and security' (Riggirozzi - Tussie 2012). The importance of its establishment lies in that it includes all Latin American countries in one grouping, which is unprecedented and also it operates independently, but in parallel with the Organization of American States providing Pan-American framework. ${ }^{6}$

During the 2014 visit of Chinese president Xi Jinping, a decision was made on CELACChina cooperation. An important element of China's foreign policy strategy is the Forum on China-Africa Cooperation and the China-Arab States Cooperation Forum launched in 2000 and 2004 respectively. Both operate through regular ministerial meetings. Along the same lines, in 2004 China proposed to launch the China-Latin America and the Caribbean Cooperation Forum, but contrary to the previous two this one failed to operate effectively. China-CELAC cooperation, however, brought new dynamism in inter-regional relations. Interestingly, China has not built institutionalized relations with the African Union or the League of Arab Nations (cooperation forums appointed only the region or a group of countries as partners), in Latin America, however, CELAC has become the official partner. It is also important because the first EU-CELAC summit meeting was organized in 2013 i.e. it

\footnotetext{
${ }^{6}$ One clear message of the establishment of CELAC is that Latin American countries want to create their own independent framework to deal with their affairs, manage their regional affairs outside the OAS system. Consequently, CELAC aims to represent whole Latin America (not only Spanish, Portuguese and French but also English and Dutch regions).
} 
seems a clear desire for Latin America to develop inter-regional relations through CELAC. As only a little time has passed, it is not possible to provide a detailed analysis on the ChinaCELAC forum, but the results of the first ministerial meeting in January 2015 in Beijing seem reassuring. Parties adopted the Plan of Cooperation between China and the Latin American and Caribbean Countries (2015-2019) ${ }^{7}$ and the Institutional Arrangements and Operating Rules of the CELAC-China Forum. China upgraded Costa Rica to become a strategic partner (as it is serving as the president of CEPAL in 2015) as well as Ecuador (to be president of CEPAL in 2016). The economic importance of the meeting is that 'Chinese leaders at the summit highlighted projections that PRC trade with the region may double in the coming decade to reach $\$ 500$ billion, while cumulative Chinese investment may reach $\$ 250$ billion during the same period.' (Ellis 2015)

The Chinese president commented on the importance of the meeting as follows: 'The time has come to deepen relations between China and Latin America (...) the ties between China and Latin America are based on the need to create a common China-CELAC destiny, for the consolidation, development and transformation of our peoples' (Granma 2015). The next ministerial meeting takes place in Chile in January 2018.

Table 2 summarizes the main forms of co-operation between China and Latin America.

Table 2. Forms of inter-regional co-operation between China and Latin America

\begin{tabular}{|c|c|c|c|}
\hline & Focus & $\begin{array}{l}\text { Direct/indirect } \\
\text { impact on China- } \\
\text { Latin America } \\
\text { relations }\end{array}$ & Examples \\
\hline Global frameworks & $\begin{array}{l}\text { Global issues, multipolarity, } \\
\text { strengthening emerging markets }\end{array}$ & Indirect impact & BRICS, G20, G21 \\
\hline $\begin{array}{l}\text { Transregional } \\
\text { groups }\end{array}$ & $\begin{array}{l}\text { Mainly economic objectives, } \\
\text { regular and strengthened } \\
\text { cooperation between regions }\end{array}$ & Indirect impact & APEC, FEALAC \\
\hline $\begin{array}{l}\text { Institutionalized } \\
\text { cooperation } \\
\text { between China and } \\
\text { Latin American } \\
\text { integration groups }\end{array}$ & $\begin{array}{l}\text { Closer economic and political } \\
\text { relations between China and } \\
\text { Latin American subregions, } \\
\text { common development }\end{array}$ & Direct impact & $\begin{array}{l}\text { China-Mercosur, China- } \\
\text { Andean Community, } \\
\text { China-CELAC, China- } \\
\text { Caribbean Economic and } \\
\text { Trade Cooperation } \\
\text { Forum }\end{array}$ \\
\hline
\end{tabular}

Source: author

\footnotetext{
${ }^{7}$ Widespread co-operation is planned in the following fields: policy and security; international affairs; trade, investment and finance; infrastructure and transportation; energy and natural resources; agriculture; industry, science and technology, aviation and aerospace; education and human resources training; culture and sports; press, media and publication; tourism; environmental protection, disaster risk management and reduction, poverty eradication and health; people-to-people friendship.
} 


\section{Conclusion}

In the twenty-first century, Sino-Latin American relations form an essential axis in SouthSouth relations. Chinese presence is far from even in Latin America: most important partners, with strong trade relations and active political cooperation are Brazil, Argentina, Chile and Peru, these Latin American states are the beneficiaries of Chinese involvement in the region. Other countries in South America (Colombia, Ecuador, Venezuela, Bolivia, Uruguay and Paraguay) are rather targets of increasing Chinese exports, till now they have not appeared in the Chinese market at a significant level. Mexico, Central America and the Caribbean are in the least advantageous position in this perspective, because they are competitors of China in the US market.

Inter-regional co-operation between China and Latin America is based on increasing trade relations and strengthening political ties in the 2000s. It forms part of third-wave, non-triadic regionalism. APEC and FEALAC are transregional groupings involving China and Latin American countries, therefore they give an opportunity for regular meetings, but it is less probable that they would lead to strengthening direct connections. The PRC has developed some kind of inter-regional cooperation with most Latin American subregions in the past two decades, which complement bilateral relations. China-Mercosur and China-Pacific Alliance relations are more promising, because these Latin American subregional groups are open for deeper inter-regional cooperation. The China-CELAC forum might be the widest and at the moment the most dynamic form of inter-regional cooperation between China and Latin America. It reflects China's motivation to build regular inter-regional frameworks with developing regions, this forum fits into the group of Chinese inter-regional cooperation frameworks. For Latin America CELAC is a tool of autonomous foreign policy and an opportunity to appear united in world affairs, therefore the China-CELAC forum is an attempt to diversify foreign relations of the region as a whole, to appear as a pole in the international system and it also legitimizes CELAC as a new actor in world politics.

The fact that China is a member of a limited number of regional organisations (Shanghai Cooperation Organisation, ASEAN+3) is an obvious limitation to inter-regional institution building from China's side, but developments of the past decade suggest that inter-regional cooperation is getting stronger between China and Latin America. Meanwhile, instead of group to group forms of cooperation, China's regular relations with Latin American 
subregional groups and CELAC seem to be the most dynamic. They provide regular forums for high-level meetings laying down future objectives and discussing possible challenges, which definitely contributes to deepening Sino-Latin American links in the future.

\section{References}

Altemani, H. (2010): Brazil and China: From South-South Cooperation to Competition? In: Fernández Jilberto, A. - Hogenboom, B. (ed.): Latin America Facing China. Relations beyond the Washington Consensus. Berhahn Books, CEDLA Latin American Studies.

Armony, A. C. - Strauss, J. C. (2012): From Going Out (zou chuqu) to Arriving In (desembarco): Constructing a New Field of Inquiry in China-Latin America Interactions. The China Quarterly 209(3):1-17.

CEPAL (2005): América Latina y el Caribe: la integración regional en la hora de las $\begin{array}{lllll}\text { definiciones. } & \text { Serie } & \text { Comercio }\end{array}$ http://www.cepal.org/es/publicaciones/4404-america-latina-y-el-caribe-la-integracionregional-en-la-hora-de-las-definiciones, accessed 10 June 2015.

CEPAL (2013): Chinese Foreign Direct Investment in Latin America and the Caribbean. Working document. http://www.cepal.org/en/publications/35927-chinese-foreign-directinvestment-latin-america-and-caribbean-china-latin-america, accessed 10 June 2015.

CEPAL (2015a): First Forum of China and the Community of Latin American and the Caribean States. Santiago.

CEPAL (2015b): Latin America and the Caribbean and China. Towards a new era in economic cooperation. Santiago.

Dosch, J. (2005): South East Asia and Latin America: A Case of Peripheral Inter-regionalism. In: Faust, J. - Mols, M. - Kim, W. (ed.): Latin America and East Asia - Attempts at Diversification. Hamburg and London: Lit.

Ellis, E. (2015): Strategic Insights: The China-CELAC Summit: Opening a New Phase in China-Latin America-U.S. Relations? Strategic Studies Institute. http://www.strategicstudiesinstitute.army.mil/index.cfm/articles/The-China-CELACSummit/2015/01/27, accessed 20 May 2015. 
Erikson, D. (2009): China's Strategy toward Central America: The Costa Rican Nexus. Jamestown Foundation China Brief (9):11. http://www.thedialogue.org/page.cfm?pageID=32\&pubID=1968, accessed 27 September 2010.

Forbes (2009): China and Peru Sign Free Trade Agreement. http://www.forbes.com/2009/05/08/peru-china-fta-business-oxford-analytica.html, accessed 27 September 2010.

Granma (2015): China-CELAC: A Strategic Alliance. http://en.granma.cu/mundo/2015-0109/china-celac-a-strategic-alliance, accessed 20 May 2015

Hänggi H. (2000): Inter-regionalism: empirical and theoretical perpectives. Paper presented for the workshop „Dollars, Democracy and Trade: External Influence on Economic Integration in the Americas", Los Angeles.

http://www.cap.lmu.de/transatlantic/download/Haenggi.PDF, accessed 27 September 2010 .

Hänggi, H. - Roloff, R. - Rüland, J. (2006): Inter-regionalism: A new phenomenon in international relations. In: Hänggi, H. - Roloff, R. - Rüland, J. (ed.): Inter-regionalism and international relations. London: Routledge.

Hettne, B. (2004): Inter-regionalism and World Order. Paper presented to the Fifth PanEuropean International Relations Conference. The Hague.

Hettne, B. (2005): Beyond the "New" Regionalism. New Political Economy 10(4): 543- 571.

IADB (2009): China joins IDB in ceremony at Bank headquarters. http://www.iadb.org/en/news/news-releases/2009-01-12/china-joins-idb-in-ceremony-atbank-headquarters,5095.html, accessed 27 September 2010.

Kim, W. (2003): The Korea-Chile FTA: Comparing Approaches to Trans-Pacific Interregionalism. Korea Institute for International Economic Policy. http://www.adbi.org/files/2003.09.30.cmats.laeba.kim.paper.pdf, accessed 27 September 2010.

Lehoczki, B. (2009): Latin-Amerika és Kina: a kapcsolatok új rendszere [Latin America and China: New System of Relations]. Szeged - Budapest: SZTE-BCE.

Lei, L. (2006): China, Latin America forge closer links for win-win end. http://www.chinaembassy.bg/eng/dtxw/t274661.htm, accessed 27 September 2010. 
Low, L. (2006): The Forum for East Asia - Latin America Cooperation (FEALAC). Embryonic interregionalims. In: Hänggi, H. - Roloff, R. - Rüland, J. (ed.): Interregionalism and international relations. London: Routledge.

People's Daily (2005): China, Andean Community to promote cooperation. http://en.people.cn/200501/28/eng20050128_172257.html, accessed 27 September 2010. Ramírez, S. (2013): Regionalism: The Pacific Alliance. Quarterly Americas 2013 Spring.

Riggirozzi, P. - Tussie, D. (ed.) (2012): The Rise of Post-Hegemonic Regionalism. The Case of Latin America. UNU Series on Regionalism. London: Springer.

Rouxel, M. (2001): El foro de cooperación América Latina-Asia del Este. Diplomacía 28(3):27-34.

Schmitter, P. - Malamud, A. (2007): Theorizing Regional Integration and Inter-Regional Relations. ECPR Joint Horkshops, Helsinki. http://ecpr.eu/events/paneldetails.aspx?PanelID=2049\&EventID=52, $\quad$ accessed 27 September 2010.

Shixue, J. (2001): Sino-Latin American Relations: Retrospects and Prospects. Research Center on Development and International Relations (DIR). Working Paper No. 98.

Söderbaum, F. - Van Langenhove, L. (2005): Introduction: The EU as a Global Actor and the Role of Inter-regionalism. Journal of European Integration 27(3): 249-262.

Steinberg, W. (2008): Strictly Business? The Rise of China in Latin American Affairs. MA Thesis for the American University, Faculty of the School of International Service.

Swaine, M. (2014): Xi Jinping's Trip to Latin America. China Leadership Monitor Fall 2014, Issue 45.

Van Langenhove, L. - Costea, A. C. - Gavin, B. (2004): From Multilateralism to Multiregionalism. What Role for Regional Integration in Global Governance? UNUCRIS Occasional Papers.

Van Langenhove, L. - Costea, A. C. (2005): Inter-regionalism and the Future of Multiregionalism. UNU-CRIS Occasional Papers.

Wilhelmy, M. - Mann, S. (2005): Multilateral Co-operation between Latin America and East Asia. In: Faust, J. - Mols, M. - Kim, W. (ed.): Latin America and East Asia-Attempts at Diversification. Hamburg and London: Lit.

Yang, B. (2015): China Voice: Right timing for China-Latin America cooperation. http://english.cntv.cn/2015/01/06/ARTI1420545003530838.shtml, accessed 20 May 2015. 